\title{
PENGEMBANGAN MODEL EVALUASI PEMBELAJARAN PROJECT BASED LEARNING BERBASIS LOGIKA FUZZY
}

\author{
Dede Irawan Saputra, Ade Gafar Abdullah, Dadang Lukman Hakim \\ Program Studi Pendidikan Teknik Elektro \\ FPTK Universitas Pendidikan Indonesia \\ Jl. Dr. Setiabudhi No. 207 Bandung \\ e-mail : dedeirawans@yahoo.co.id
}

\begin{abstract}
Abstrak. Makalah ini memaparkan hasil pengembangan model evaluasi pembelajaran dari serangkaian dimensi penilaian portofolio, proyek, presentasi proyek dan tes tulis. Penelitian dilaksanakan pada kegiatan praktikum teknik analog melalui model pembelajaran project based learning $(\mathrm{PjBL})$. Logika fuzzy merupakan suatu alternatif alat pengambil keputusan yang dapat diaplikasikan untuk mengevaluasi hasil pembelajaran. Keputusan akhir dalam evaluasi PjBL menghasilkan proses evaluasi yang tidak kaku dan objektif karena keputusan akhir dapat ditentukan melalui proses defuzzifikasi yang sepenuhnya dilakukan menggunakan fuzzy logic toolbox. Model evaluasi berbasis logika fuzzy diharapkan mendapat trend yang baik dan bisa menjadi petunjuk untuk mengembangkan model evaluasi yang diadopsi di sekolah.

Kata kunci: evaluasi pembelajaran, Project-Based Learning, logika fuzzy

Abtract. This paper presents the results of the development of learning evaluation model, consisting of an assessment of portfolio, project, project presentations, and written tests. The experiment was conducted in laboratory activities through project-based learning (PjBL). Fuzzy logic is an alternative decision-making tool that can be applied to evaluate the learning outcomes. The final decision in the evaluation of PjBL resulted in the evaluation process are not rigid and objective because the latest decision can be determined through a defuzzification process is entirely carried out using the fuzzy logic toolbox. Fuzzy logic-based evaluation model is expected to get a positive trend and could be a suggestion to develop an evaluation model to be adopted at schools.
\end{abstract}

Keywords : learning outcomes, Project-Based Learning, fuzzy logic.

\section{PENDAHULUAN}

Pembelajaran adalah proses interaksi antara siswa dengan lingkungannya sehingga terjadi perubahan perilaku yang lebih baik. Dalam proses pembelajaran prinsip utamanya adalah adanya proses keterlibatan seluruh potensi siswa. Proses ini menuntut sikap kritis dari si pengajar dan pembelajar (Rohman, 2007). Memotivasi dan menarik siswa dalam proses pembelajaran aktif adalah sebuah tantangan bahkan bagi guru yang sudah berpegalaman pun (Yussof, 2006).

Salah satu masalah yang dihadapi dunia pendidikan adalah masalah lemahnya proses pembelajaran dan evaluasi pembelajaran. Satu contoh dapat disajikan hasil temuan mengenai representasi pada penggunaan motivasi, media dan metode yang sesuai karakteristik siswa untuk mengoptimalkan kepekaan sensori siswa (Pardjono dan Windiyati, 2012) dan hasil temuan tentang sebagian 
besar guru tidak tertarik dan tidak mau menggunakan penilaian autentik atau penilaian berbasis kinerja (Rustaman, 2006).

Proses praktikum diarahkan kepada kemampuan anak untuk melatih keterampilan-keterampilan yang dibutuhkan dan memberikan kesempatan siswa untuk menerapkan dan mengintegrasikan pengetahuan dan keterampilannya secara nyata dalam praktik dan dapat dihubungkan dengan kehidupan sehari-hari. Berdasarkan hasil observasi yang dilakukan ditempat penelitian, proses praktikum hanya dilakukan dengan melaksanakan tugas yang tersedia di jobsheet dan proses penilaian yang dilakukan belum menyeluruh, penilaian hanya diambil dari tahap akhir kegiatan praktikum saja yaitu tuntas atau tidak tuntas. Akibatnya tidak ada bukti autentik dari proses praktikum dan bukti perkembangan belajar siswa.

Pembelajaran Teknik Analog sarat dengan konsep dan teknik terutama dalam menerapkan sistem audio, sehingga diperlukan pemahaman dan keterampilan yang baik terhadap konsep penguat daya. Salah satu indikator pembelajaran teknik analog di SMK adalah mengidentifikasi karakteristik penguat daya.

Model Project Based Learning (PjBL) merupakan salah satu inovasi dalam pembelajaran yang dapat digunakan, karena PjBL bertujuan melatih siswa dalam berpikir kritis, kreatif dan rasional, aktif berkolaborasi dan berkomunikasi, dan meningkatkan pemahaman materi yang diajarkan serta memberi pengalaman nyata terhadap siswa. Kelebihan dari PjBL adalah proyek yang dapat dipilih atau dikembangkan untuk mencapai hasil pembelajaran tertentu. Tujuannya agar siswa mampu mempunyai kemandirian dan keterampilan dalam menyelesaikan tugas yang dihadapinya. Hasil penelitian menyimpulkan bahwa $\mathrm{PjBL}$ terbukti dan teruji sebagai model pembelajaran yang mampu menumbuhkan kemandirian siswa, khususnya pada pembelajaran yang memungkinkan untuk dilaksanakan kerja proyek (Wena,2009).

Dalam materi penguat daya, terdapat berbagai indikator dan tujuan belajar yang kompleks dan sulit diamati hanya dengan mengandalkan hasil akhir dari kegiatan praktikum maupun tes tulis saja. oleh karena itu agar hasil pembelajaran dapat membandingkan kinerja dari berbagai dimensi, tidak hanya hasil saja dan merupakan penilaian autentik, maka dikembangkan rubrik-rubrik penilaian pada 
PjBL. Evaluasi pembelajaran berdasarkan variabel-variabel penilaian pada $\mathrm{PjBL}$ memberikan pertimbangan-pertimbangan dari berbagai aspek keperluan pembelajaran, seperti prinsip objektivitas penilaian di industri dengan tujuan menunjukan hasil yang adil dan metode yang objektif (Zhou, 2001: 1).

Teknik tes dan nontes dapat digunakan sebagai alat evaluasi hasil belajar. Teknik nontes tidak menggunakan kunci jawaban dalam menentukan skor, melainkan menggunakan pedoman penilaian berupa rubrik. Rubrik tersebut berupa rating scales (skala rating) yang secara spesifik merupakan format dari instrumen penilaian untuk mengukur kerja siswa atau produk yang dihasilkan siswa pada tugas dalam pembelajaran sedangkan teknik tes untuk tes tulis menggunakan kunci jawaban (Sudijono, 2012).

Permasalahan yang muncul pada penelitian adalah menentukan hasil akhir dari serangkaian variabel-variabel penilaian yang dilakukan terhadap siswa sehingga dibutuhkan sebuah model evaluasi untuk membuat keputusan akhir. Model Stake menitikberatkan evaluasi pada dua hal pokok, yaitu description dan judgement. Evaluasi dilakukan dengan membandingkan antara satu program dengan program lain yang dianggap standar (Arifin, 2010). Program pada penelitian berupa serangkaian penilaian pada pembelajaran teknik analog. Penilaian tersebut adalah penilaian portofolio, proyek, presentasi proyek dan tes tulis.

Dalam banyak hal, logika fuzzy digunakan sebagai suatu cara untuk memetakan permasalahan dari input menuju ke output yang diharapkan (Kusumadewi, 2010). Logika fuzzy sudah meluas digunakan dalam berbagai bidang, tidak hanya dibidang industri, logika fuzzy juga dapat digunakan dalam bidang pendidikan, diantaranya teknik dari logika fuzzy dapat diadaptasi untuk mengevaluasi hasil belajar siswa (Bai, 2008) (Venkatsen, 2008), mengevaluasi prestasi belajar siswa (Ingoley, 2012), digunakan dalam pengklasifikasian siswa (Nykänen, 2006), menilai proyek siswa (Zhou, 2001), optimalisasi evaluasi kinerja siswa (Sakthivel, 2013) dan mengevaluasi kinerja siswa di laboratorium praktikum (Gokmen, 2010). Pada penelitian, logika fuzzy digunakan sebagai alat pendukung keputusan dan evaluasi pembelajaran PjBL dari serangakaian penilaian yang dilakukan pada pembelajaran teknik analog dengan empat variabel 
input dan satu variabel output. Variabel input tersebut terdiri dari penilaian portofolio, proyek, presentasi dan tes tulis. Variabel output adalah hasil akhir evaluasi PjBL.

\section{METODE}

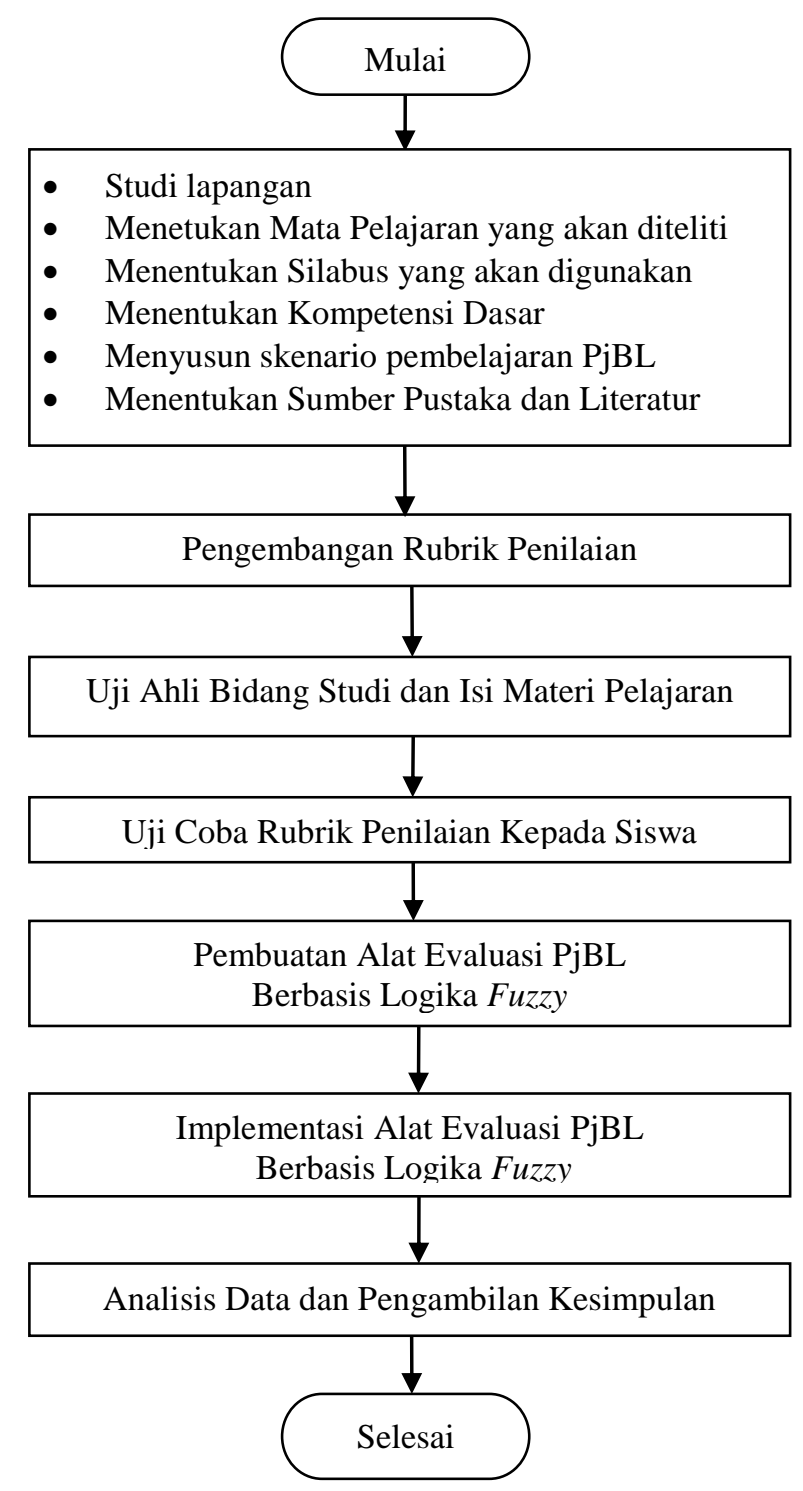

Gambar 1. Diagram alir penelitian

Penelitian dilakukan dengan menggunakan pendekatan kualitatif dan strategi kualitatif yang digunakan adalah studi kasus karena tujuannya untuk mengeksplorasi, mendeskripsikan dan menggambarkan apa adanya mengenai suatu gejala atau keadaan yang dianggap berasal dari masalah sosial atau kemanusiaan. Langkah pengumpulan data meliputi pembatasan penelitian, mengumpulkan informasi melalui observasi dan wawancara, dokumentasi, materi- 
materi visual dan catatan lapangan. Berikut tahapan pada penelitian yang ditunjukan Gambar 1.

Tahap pertama yang dilakukan adalah studi lapangan, peneliti langsung mendatangi SMK Negeri 1 Cimahi kemudian mengadakan wawancara dan observasi ke program keahlian Elektronika Industri untuk menentukan mata pelajaran yang akan diteliti kemudian menentukan silabus yang akan digunakan, serta menentukan kompetensi dasar. Silabus yang digunakan pada proses penelitian adalah silabus mata pelajaran teknik analog. Setelah menentukan silabus yang digunakan peneliti menentukan standar kompetensi dan kompetensi dasar yang akan diteliti. Standar kompetensi yang diteliti adalah mengoperasikan rangkain elektronika terapan dan kompetensi dasar menerapkan sistem audio dan video. Selanjutnya menentukan sumber referensi yang digunakan.

Tabel 1. Skenario pembelajaran PjBL

\begin{tabular}{|c|c|}
\hline Kegiatan Guru & KegiatanSiswa \\
\hline Membuat pertanyaan-pertanyaan ilmiah & $\begin{array}{l}\text { Menjawab dan mendiskusikan hasil dari } \\
\text { pertanyaan-pertanyaan ilmiah yang } \\
\text { disampaikan melalui praktikum }\end{array}$ \\
\hline $\begin{array}{l}\text { Mendesain sebuah proyek untuk menyelesaikan } \\
\text { pertanyaan yang telah dirumuskan, melakukan } \\
\text { kajian teoritis }\end{array}$ & $\begin{array}{l}\text { Mengaplikasikan kegiatan praktikum } \\
\text { menjadi sebuah produk }\end{array}$ \\
\hline Menjalankan observasi dan experimen & $\begin{array}{l}\text { Membuat kelompok dan menyusun jadwal } \\
\text { pengerjaan proyek }\end{array}$ \\
\hline $\begin{array}{l}\text { Memonitor praktikum siswa dan memonitor } \\
\text { perkembangan proyek }\end{array}$ & $\begin{array}{l}\text { Mengejakan praktikum dan melanjutkan } \\
\text { pengerjaan proyek }\end{array}$ \\
\hline Menilai keseluruhan hasil produk & $\begin{array}{l}\text { Menyimpulkan produk yang telah } \\
\text { dibuat,mepresentasikannya dan membuat } \\
\text { laporan proyek }\end{array}$ \\
\hline $\begin{array}{l}\text { evaluasi aktivitas belajar dan hasil proyek yang } \\
\text { sudah dijalankan }\end{array}$ & $\begin{array}{l}\text { Mengumpulkan penilaian portofolio } \\
\text { praktikum, penilaian proyek, presentasi dan } \\
\text { tes tulis }\end{array}$ \\
\hline
\end{tabular}

Tahap kedua adalah mendesain skenario pembelajaran PjBL (Tabel 1.) dengan berdiskusi bersama guru bidang studi, menentukan variabel-variabel penilaian dan rubrik penilaian yang akan digunakan. Penilaian yang akan dilaksanakan pada $\mathrm{PjBL}$ adalah penilaian portofolio praktikum penguat kelas $\mathrm{A}$ dan $\mathrm{B} / \mathrm{AB}$ push-pull, penilaian proyek siswa membuat penguat audio, penilaian presentasi proyek siswa dan tes tulis siswa. Pembatasan dilakukan sebagai upaya untuk meningkatkan kecermatan. Penelitian pelaksanaan skenario pembelajaran dibatasi waktunya tidak terlalu lama, yaitu selama 3 pertemuan dengan dua pertemuan untuk penilaian portofolio praktikum dan proyek dan satu pertemuan 
untuk penialaian partisipasi presentasi proyek dan tes tulis. Berikut skenario pembelajaran $\mathrm{PjBL}$ yang digunakan.

Setelah rubrik penilaian selesai dibuat, tahap ketiga adalah pengujian rubrik penilaian kepada tim ahli. Tim ahli berjumlah 5 orang yang terdiri dari tim ahli di bidang studi dan isi materi pelajaran dari beberapa program keahilan yang ada di SMK Negeri 1 Cimahi, diantaranya adalah program keahlian Elektronika Industri, Teknik Otomasi Industri, Teknik Transmisi dan Teknik Komputer Jaringan. Proses uji ahli dilakukan untuk menilai apakah rubrik yang akan digunakan dalam PjBL sudah sesuai dengan silabus, SKKD dan dapat diaplikasikan pada mata pelajaran teknik analog.

Setelah melakukan pengujian kepada tim ahli, selanjutnya adalah melakukan perbaikan terhadap rubrik-rubrik yang telah dibuat berdasarkan saran dan masukan yang didapat. Setelah tahap ketiga dan dilaksanakan perbaikan terhadap rubrik yang akan digunakan, selanjutkanya adalah tahap keempat yaitu tahap penelitian yang berupa pengujian rubrik penilaian kepada siswa kelas XI Elektronika Industri B yang berjumlah 34 siswa pada mata pelajaran teknik analog dengan model pembelajaran PjBL. Pengujian dilakukan dengan tujuan untuk mendapatkan nilai siswa dalam pembelajaran teknik analog.

Tahap kelima dari penelitian adalah pembuatan alat evaluasi pembelajaran PjBL berbasis logika fuzzy. Pembuatan alat evaluasi pembelajaran dilakukan setelah rubrik-rubrik yang dibuat valid. Adapun yang dievaluasi dari proses pembelajaran adalah hasil pembelajaran pada mata pelajaran teknik analog dengan mengolah nilai portofolio praktikum siswa, proyek siswa, presentasi proyek siswa dan tes tulis. Keempat nilai siswa tersebut dievaluasi menggunakan aturan-aturan logika fuzzy yang didapat dari hasil studi pustaka dan studi lapangan.

Setelah alat evaluasi dibuat, masuk ke tahap keenam penelitian yaitu implementasi alat evalaluasi PjBL berbasis logika fuzzy dengan memasukan keempat nilai siswa yang didapat ketika pembelajaran teknik analog. Implementasi yang dilakukan untuk mengetahui kemempuan alat evaluasi dalam menyelesaikan maslah subjektivitas pada penilaian.

Setelah semua penilaian pada pembelajaran teknik analog menggunakan PjBL dievaluasi menggunakan logika fuzzy, tahap selanjutkan adalah analisis data 
dan pengambilan kesimpulan hasil dari implementasi produk evaluasi pembelajaran PjBL berbasis logika fuzzy. Yaitu kemampuan dalam mengevaluasi pembelajaran PjBL. Analisis data dilakukan dengan teknik analisis naratif deskriptif.

Masing-masing cara kerja dari proses penelitian yaitu pengamatan nonpartisipatif, pengamatan partisipatif, wawancara, analisis dokumen dan mengembangkan cara serta rencana tersendiri untuk mengumpulkan data dalam proses penggalian informasi di lapangan. Studi kasus adalah penelitian yang bisa meliputi pemeriksaan sangat teliti tentang aktivitas atau program pembelajaran.

\section{HASIL DAN PEMBAHASAN}

Teknik yang digunakan dalam evaluasi PjBL adalah teknik non-tes dan tes. Teknik non-tes yang digunakan pada penelitian adalah menggunakan penilaian portofolio, proyek dan presentasi sedangkan untuk teknik tes menggunakan tes uraian. Dengan teknik non-tes maka penilaian hasil belajar siswa dilakukan tanpa menguji siswa, melainkan dilakukan dengan pengamatan. Pengamatan yang dilakukan pada proses penelitian adalah pengamatan untuk nilai portofolio, proyek dan presentasi.

Variabel penilaian portofolio praktikum dibuat karena dapat dijadikan penentuan pertanyaan mendasar dan permasalahan terhadap proyek yang akan ditugaskan dan dikerjakan oleh siswa. Penilaian portofolio praktikum dilaksanakan untuk menilai proses praktikum penguat kelas $\mathrm{A}$ dan $\mathrm{B} / \mathrm{AB}$ pushpull sekaligus mengumpulkan semua dokumen hasil praktikum setiap siswa dalam satu tempat. Portofolio merupakan penilaian berkelanjutan yang didasarkan pada kumpulan informasi yang menunjukan perkembangan siswa dalam praktikum. Variabel penilaian yang kedua adalah penilaian proyek. Penilaian proyek merupakan kegiatan penilaian terhadap tugas proyek kelompok membuat penguat audio yang harus diselesaikan dalam waktu tertentu yang mencakup didalamnya adalah proses penyusunan rencana proyek, menyusun jadwal proyek, proses pengerjaan proyek, laporan proyek dan menguji produk yang dihasilkan siswa dari tugas proyek. Variabel penilaian yang ketiga adalah sebagai refleksi dari aktivitas dan hasil pengerjaan proyek siswa yaitu dilaksanakan penilaian presentasi proyek siswa. 
Teknik kedua adalah teknik tes. Tes dalam penelitian adalah tes tulis yang dilakukan untuk mengungkap daya ingat dan pemahaman siswa terhadap materi pelajaran. Setelah ditentukan serangkaian proses penilaian yang akan diambil pada $\mathrm{PjBL}$, selanjutnya penentuan rubrik-rubrik dari setiap penilaian.

Dari teknik tes dan non tes, siswa diharapkan dapat mengembangkan softskill dalam praktikum. siswa dituntut untuk aktif berkomunikasi, berkolaborasi dan bertanggung jawab serta berpikir kritis, kreatif dan rasional dalam menyelesaikan tugas. Dalam pengembangannya rubrik-rubrik telah melalui ujicoba ahli isi/mata pelajaran dan uji coba terbatas pada satu kelas. Rubrik yang dikembangan menggunakan skala rating 4, artinya pencapaian kompetensi terbanyak adalah 4. Rubrik-rubrik tersebut terdiri dari lembar penilaian dan pedoman penilaian dan pemberian skor mengacu pada pedoman penilaian. Berikut ditampilkan lembar penilaian dari setiap rubrik yang dikembangkan:

\section{Rubrik Portofolio}

Pada penelitian, portofolio yang digunakan terdiri dari tiga, yaitu portofolio proses praktikum, portofolio laporan praktikum dan portofolio tugas mandiri. Berikut tanggapan anggapan salah satu responden: "Dengan penilaian portofolio hasil evaluasi bisa lebih jelas dari aspek apa saja yang akan dinilai secara rinci lebih deskriptif'. Berikut lembar penilaian untuk portofolio pada Gambar 2-5.

Tabel 2. Lembar penilaian portofolio proses praktikum

\begin{tabular}{|c|c|c|c|c|c|c|}
\hline \multirow{2}{*}{ No } & \multirow{2}{*}{ Kriteria/subkriteria penilaian } & \multicolumn{4}{|c|}{ Pencapaian kompetensi } & \multirow[t]{2}{*}{ skor } \\
\hline & & 4 & 3 & 2 & 1 & \\
\hline \multirow{5}{*}{1.} & \multicolumn{6}{|l|}{ Tahap persiapan praktikum } \\
\hline & Menaati peraturan & & & & & \\
\hline & Membawa alat kerja & & & & & \\
\hline & Memeriksa komponen & & & & & \\
\hline & Skor rata-rata kriteria & & & & & \\
\hline \multirow{8}{*}{2.} & \multicolumn{6}{|l|}{ Tahap pelaksanaan praktikum } \\
\hline & Merakit rangkaian penguat kelas A & & & & & \\
\hline & Menyambungkan dengan sumber dan osiloskop & & & & & \\
\hline & Mengidentifikasi sinyal input dan output & & & & & \\
\hline & $\begin{array}{l}\text { Mengidentifikasi dan mencatat perhitungan sesuai } \\
\text { jobsheet }\end{array}$ & & & & & \\
\hline & Identifikasi troubleshooting & & & & & \\
\hline & Menarik kesimpulan & & & & & \\
\hline & Skor rata-rata kriteria & & & & & \\
\hline \multirow{4}{*}{3.} & Tahap akhir praktikum & & & & & \\
\hline & Penggunaan waktu & & & & & \\
\hline & Merapikan dan mengembalikan peralatan praktikum & & & & & \\
\hline & Membuat laporan sementara praktikum & & & & & \\
\hline
\end{tabular}




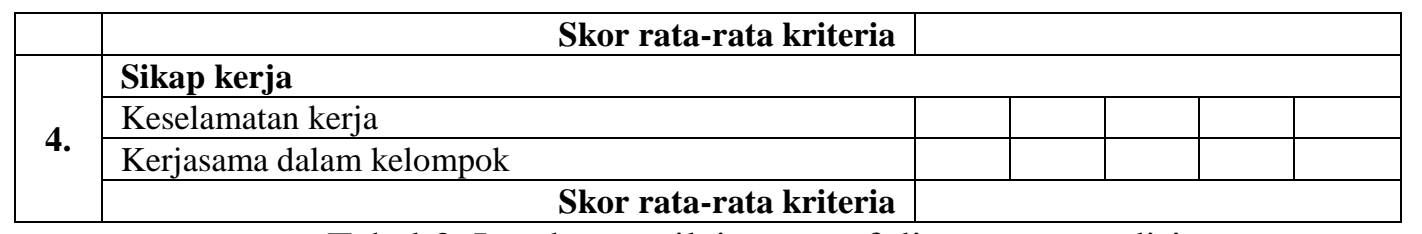

Tabel 3. Lembar penilaian portofolio tugas mandiri

\begin{tabular}{|c|c|c|c|c|c|c|}
\hline \multirow{2}{*}{ No. } & \multirow{2}{*}{ Kriteria/subkriteria penilaian } & \multicolumn{4}{|c|}{ Pencapaian kompetensi } & \multirow{2}{*}{ skor } \\
\hline & & 4 & 3 & 2 & 1 & \\
\hline \multirow[t]{2}{*}{1.} & \multicolumn{6}{|l|}{ Waktu pengumpulan tugas mandiri } \\
\hline & Ketepatan pengumpulan tugas & & & & & \\
\hline \multirow[t]{7}{*}{2.} & Hasil tugas & & & & & \\
\hline & Gambar rangkaian & & & & & \\
\hline & Hasil simulasi & & & & & \\
\hline & Rumus dan perhitungan & & & & & \\
\hline & Kesimpulan & & & & & \\
\hline & \multicolumn{5}{|l|}{ Total skor } & \\
\hline & \multicolumn{5}{|l|}{ Skor rata-rata } & \\
\hline
\end{tabular}

Tabel 4. Lembar peniilaian portofolio laporan praktikum

\begin{tabular}{|c|c|c|c|c|c|c|}
\hline \multirow{2}{*}{ No. } & \multirow{2}{*}{ Kriteria/subkriteria penilaian } & \multicolumn{4}{|c|}{ Pencapaian kompetensi } & \multirow{2}{*}{ skor } \\
\hline & & 4 & 3 & 2 & 1 & \\
\hline \multirow[t]{2}{*}{1.} & \multicolumn{6}{|c|}{ Waktu pengumpulan laporan individu praktikum } \\
\hline & Ketepatan pengumpulan laporan individu & & & & & \\
\hline \multirow[t]{8}{*}{2.} & \multicolumn{6}{|l|}{ Laporan individu } \\
\hline & Tujuan & & & & & \\
\hline & Dasar teori & & & & & \\
\hline & Alat dan bahan & & & & & \\
\hline & Langkah kerja & & & & & \\
\hline & Analisis dan pembahasan & & & & & \\
\hline & Kesimpulan & & & & & \\
\hline & Daftar pustaka & & & & & \\
\hline \multicolumn{7}{|c|}{ Total skor } \\
\hline \multicolumn{6}{|c|}{ Skor rata-rata } & \\
\hline
\end{tabular}

Tabel 5. Perhitungan nilai portofolio

\begin{tabular}{|c|c|c|c|c|c|c|c|}
\hline \multicolumn{7}{|c|}{ PROSENTASE BOBOT KRITERIA PENILAIAN } & \multirow{2}{*}{$\begin{array}{c}\text { Nilai } \\
\text { portofolio }\end{array}$} \\
\hline Kriteria & $\begin{array}{c}\text { Tahap } \\
\text { persiapan }\end{array}$ & $\begin{array}{c}\text { Tahap } \\
\text { pelaksanaan }\end{array}$ & $\begin{array}{l}\text { Tahap } \\
\text { akhir }\end{array}$ & $\begin{array}{l}\text { Sikap } \\
\text { kerja }\end{array}$ & $\begin{array}{l}\text { Laporan } \\
\text { individu }\end{array}$ & $\begin{array}{c}\text { Tugas } \\
\text { mandiri }\end{array}$ & \\
\hline Bobot $(\%)$ & 10 & 30 & 10 & 15 & 20 & 15 & \\
\hline \multicolumn{7}{|l|}{ Praktikum 1} & \\
\hline \multicolumn{7}{|l|}{ Praktikum 2} & \\
\hline \multicolumn{7}{|l|}{ Skor kriteria } & \\
\hline Nilai kriteria & & & & & & & \\
\hline
\end{tabular}

Tabel 5 menjelaskan perhitungan untuk portofolio siswa. Skor kriteria adalah perkalian dari skor rata-rata kriteria tiap portofolio dengan 25 dari praktikum $1 \& 2$, nilai kriteria adalah perkalian dari skor kriteria dengan bobot dan nilai portofolio adalah jumlah dari hasil perhitungan nilai kriteria. 


\section{Rubrik Penilaian Proyek}

Variabel penilaian yang kedua adalah penilaian proyek. Berikut tanggapan salah satu responden: "Dengan penilaian proyek dapat menilai kesesuaian proyek yang direncanakan, kemampuan mengelola proyek yang ditugaskan dan keaslian produk yang dihasilkan".

Tabel 6. Lembar penilaian proyek

\begin{tabular}{|c|c|c|c|c|c|c|}
\hline No & Kriteria/subkriteria penilaian & \multicolumn{4}{|c|}{ Pencapaian kompetensi } & skor \\
\hline & & 4 & 3 & 2 & 1 & \\
\hline \multirow[t]{8}{*}{$\mathbf{I}$} & \multicolumn{6}{|l|}{ TAHAP PERISAPAN PEMBUATAN PROYEK } \\
\hline & \multicolumn{6}{|l|}{ Laporan konsep siswa } \\
\hline & \multicolumn{6}{|l|}{ Tujuan } \\
\hline & \multicolumn{6}{|l|}{ Alat dan bahan } \\
\hline & \multicolumn{6}{|l|}{ Langkah kerja } \\
\hline & \multicolumn{6}{|l|}{ Membuat jadwal proyek } \\
\hline & Terdapat jadwal pengerjaan proyek & & & & & \\
\hline & Skor rata-rata kriteria: & & & & & \\
\hline \multirow[t]{13}{*}{ II. } & \multicolumn{6}{|c|}{ TAHAP PELAKSANAAN PEMBUATAN PROYEK } \\
\hline & \multicolumn{6}{|c|}{ Komponen elektronika dirakit menjadi pesawat elektronika } \\
\hline & \multicolumn{6}{|l|}{ Kelengkapan komponen } \\
\hline & \multicolumn{6}{|l|}{ Layout pesawat elektronika } \\
\hline & \multicolumn{6}{|l|}{ Pembuatan PCB } \\
\hline & \multicolumn{6}{|l|}{ Ketentuan spesifikasi komponen } \\
\hline & \multicolumn{6}{|l|}{ Tata letak komponen elektronika } \\
\hline & \multicolumn{6}{|l|}{ Tata letak komponen } \\
\hline & \multicolumn{6}{|l|}{ Sambungan terjalin } \\
\hline & \multicolumn{6}{|l|}{ Membuat penghubung jack input } \\
\hline & \multicolumn{6}{|l|}{ Penggunaan kabel audio } \\
\hline & \multicolumn{6}{|l|}{ Grounding } \\
\hline & Skor rata-rata kriteria: & & & & & \\
\hline \multirow[t]{3}{*}{ III } & \multicolumn{6}{|l|}{ HASIL PROYEK } \\
\hline & Alat berfungsi & & & & & \\
\hline & Skor rata-rata kriteria: & & & & & \\
\hline \multirow[t]{12}{*}{ IV } & \multicolumn{6}{|l|}{ TAHAP AKHIR PEMBUATAN PROYEK } \\
\hline & Waktu penyelesaian proyek & & & & & \\
\hline & Ketepatan penyelesaian proyek & & & & & \\
\hline & Laporan akhir proyek & & & & & \\
\hline & Tujuan & & & & & \\
\hline & Dasar teori & & & & & \\
\hline & Alat dan bahan & & & & & \\
\hline & Langkah kerja & & & & & \\
\hline & Analisis dan pembahasan & & & & & \\
\hline & Kesimpulan & & & & & \\
\hline & Daftar pustaka & & & & & \\
\hline & Skor rata-rata kriteria: & & & & & \\
\hline $\mathbf{V}$ & SIKAP KERJA & & & & & \\
\hline & Mengutamakan K3 & & & & & \\
\hline & Kerjasama & & & & & \\
\hline & Skor rata-rata kriteria: & & & & & \\
\hline
\end{tabular}


Tabel 7. Perhitungan nilai proyek

\begin{tabular}{|c|c|c|c|c|c|c|}
\hline \multicolumn{6}{|c|}{ PROSENTASE BOBOT KRITERIA PENILAIAN } & \multirow[b]{2}{*}{$\begin{array}{c}\text { Nilai } \\
\text { proyek }\end{array}$} \\
\hline Kriteria & $\begin{array}{c}\text { Tahap } \\
\text { persiapan }\end{array}$ & $\begin{array}{c}\text { Tahap } \\
\text { pelaksanaan }\end{array}$ & $\begin{array}{c}\text { Hasil } \\
\text { proyek }\end{array}$ & $\begin{array}{l}\text { Tahap } \\
\text { akhir }\end{array}$ & $\begin{array}{l}\text { Sikap } \\
\text { kerja }\end{array}$ & \\
\hline Bobot $(\%)$ & 10 & 30 & 25 & 15 & 20 & \\
\hline \multicolumn{6}{|l|}{ rata-rata kriteria } & \\
\hline \multicolumn{6}{|l|}{ Skor kriteria } & \\
\hline Nilai Kriteria & & & & & & \\
\hline
\end{tabular}

Perhitungan untuk proyek ditunjukan pada Tabel 7. Skor kriteria adalah perkalian dari skor rata-rata kriteria dari tahapan-tahpan pengerjaan proyek dengan 25, nilai kriteria adalah perkalian dari skor kriteria dengan bobot dan nilai portofolio adalah jumlah dari hasil perhitungan nilai kriteria.

\section{Rubrik Penilaian Presentasi Proyek}

Variabel penilaian yang ketiga adalah penilaian presentasi proyek. Tanggapan dari salah satu responden diantaranya: "Dengan presenasi dapat melatih meningkatkan kepercayaan diri dalam berargumentasi. Secara keseluruhan rubrik presentasi sudah dapat merepresentasikan kemampuan siswa dlihat dari segi penampilan".

Tabel 8. Lembar penilaian presentasi proyek

\begin{tabular}{|c|c|c|c|c|c|c|}
\hline \multirow{2}{*}{ No. } & \multirow{2}{*}{ Kriteria/subkriteria penilaian } & \multicolumn{4}{|c|}{ Pencapaian kompetensi } & \multirow{2}{*}{ skor } \\
\hline & & 4 & 3 & 2 & 1 & \\
\hline \multirow[t]{8}{*}{1.} & \multicolumn{6}{|l|}{ Menjadi penyaji } \\
\hline & Menjabarkan isi dan menyampaikan hasil proyek & & & & & \\
\hline & Organisasi alur penyampaian informasi & & & & & \\
\hline & Gerakan mata dan tubuh & & & & & \\
\hline & Suara & & & & & \\
\hline & Penggunaan penunjang presentasi & & & & & \\
\hline & Menjawab pertanyaan dengan benar & & & & & \\
\hline & Skor rata-rata kriteria & & & & & \\
\hline \multirow[t]{6}{*}{2.} & \multicolumn{6}{|l|}{ Menjadi audien } \\
\hline & Memerhatikan penyaji & & & & & \\
\hline & Tenang dalam kelas & & & & & \\
\hline & Sopan dalam bertanya dan menjawab & & & & & \\
\hline & Mengikuti prosedur presentasi & & & & & \\
\hline & Skor rata-rata kriteria & & & & & \\
\hline
\end{tabular}

Perhitungan penilaian untuk presentsi ditunjukan pada Tabel 9. Skor kriteria adalah perkalian dari skor rata-rata kriteria dari tahapan-tahpan pengerjaan presentasi proyek dengan 25, nilai kriteria adalah perkalian dari skor kriteria 
dengan bobot dan nilai portofolio adalah jumlah dari hasil perhitungan nilai kriteria.

Tabel 9. Perhitungan nilai presentasi proyek

\begin{tabular}{|l|c|c|c|}
\hline \multicolumn{2}{|c|}{ PROSENTASE BOBOT KRITERIA PENILAIAN } & Nilai presentasi \\
\hline \multicolumn{1}{|c|}{ Kriteria } & Menjadi Penyaji & Menjadi Audien & \multirow{2}{*}{40} \\
\cline { 1 - 3 } Bobot (\%) & 60 & & \\
\hline Skor rata-rata kriteria & & & \\
\hline Skor kriteria & & & \\
\hline Nilai Kriteria & & & \\
\hline
\end{tabular}

\section{Tes Tulis}

Variabel penilaian yang keempat adalah tes tulis. Maksud dari penggunaan tes tulis pada penelitian adalah untuk melihat berbagai kemampuan yang dimiliki siswa dalam bentuk tertulis seperti menggambar rangkaian, penggunaan rumus dan proses perhitungan. Berikut tanggapan dari responden: “ ... dengan tes tulis uraian bisa melihat kemampuan menghitung dan menulis rumus-rumus yang sudah dikasih sebelumnya ...".

Untuk membuat model evaluasi pembelajaran PjBL (dari serangkaian dimensi penilaian portofolio, proyek, presentasi proyek dan tes tulis) berbasis logika fuzzy dapat dilakukan melalui langkah-langkah fuzzifikasi, inferensi dan defuzzifikasi.

Fuzzifikasi adalah suatu proses mengubah variabel numerik menjadi variabel linguistik. Misalnya telah disepakati tingkatan nilai untuk penilaian portofolio adalah SB "Sangat Baik", B “Baik”, C "Cukup” dan K “Kurang”. Pada penelitian, logika fuzzy digunakan sebagai alat pendukung keputusan dan evaluasi pembelajaran $\mathrm{PjBL}$ dari serangakaian penilaian yang dilakukan pada pembelajaran teknik analog dengan empat variabel input dan satu variabel output. Variabel input tersebut terdiri dari penilaian portofolio, proyek, presentasi dan tes tulis. Variabel output adalah hasil akhir evaluasi PjBL. Input dan output evaluasi pembelajaran memiliki range dari 0-100 sesuai yang disepakati. Langkah fuzzifikasi dilakukan menggunakan fuzzy logic toolbox pada matlab.

Variabel input pertama adalah penilaian portofolio. Maka hubungan tingkatan nilai portofolio dengan fungsi keanggotaannya dapat ditulis: 


$$
\begin{gathered}
\mu_{K}(x)=\left\{\begin{array}{cc}
0 & 50 \leq x \leq 100 \\
(50-x) / 50, & 0<x \leq 50
\end{array}\right. \\
\mu_{C}(x)\left\{\begin{array}{cc}
0 & 0 \leq x \leq 30 \\
(x-30) / 20, & 30<x \leq 50 \\
(60-x) / 10, & 50<x \leq 60 \\
0 \quad, & 60<x \leq 100
\end{array}\right. \\
\mu_{B}(x)\left\{\begin{array}{cc}
0 \leq x \leq 50 \\
(x-50) / 5, & 50<x \leq 65 \\
(80-x) / 10, & 60<x \leq 80
\end{array}\right. \\
\mu_{S B}(x)=\left\{\begin{array}{cc}
0 & 80<x \leq 100 \\
(x-70) / 30, & 70<x \leq 100
\end{array}\right.
\end{gathered}
$$

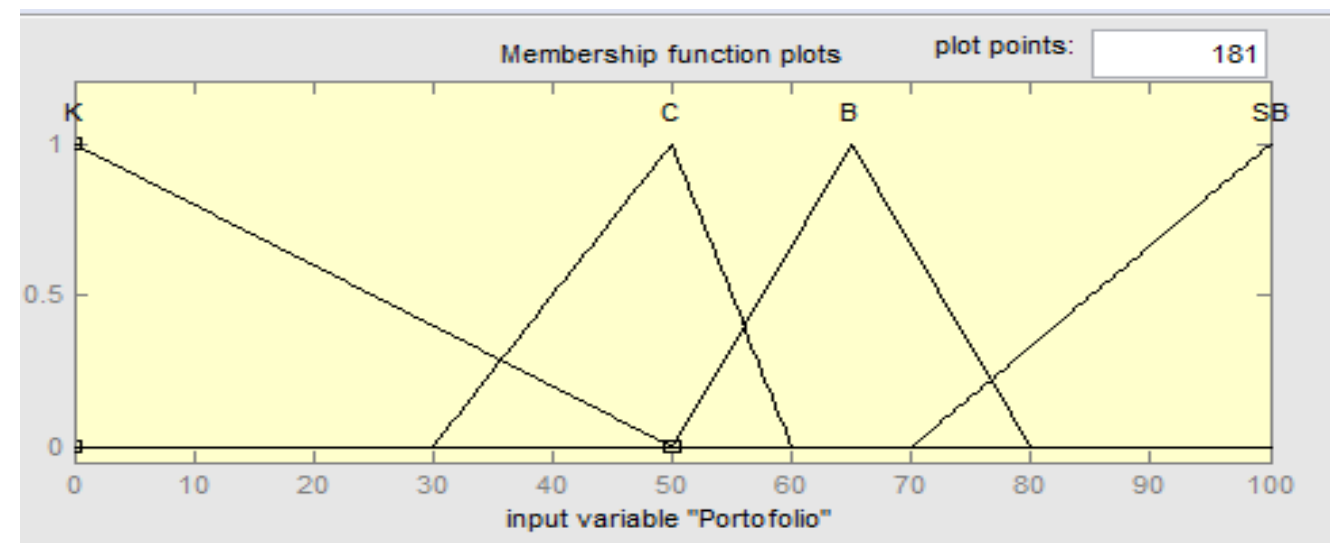

Gambar 2. Fuzzifikasi portofolio

Pada Gambar 2 menunjukkan hubungan antara masing-masing tingkatan penilaian pada penilaian portofolio praktikum yang berperan sebagai input dengan fungsi keanggotaan fuzzy yang dibuat dengan menggunakan fungsi keanggotaan model segitiga.

Variabel input kedua adalah penilaian proyek. Maka hubungan tingkatan nilai proyek dengan fungsi keanggotaannya dapat ditulis:

$$
\begin{gathered}
\mu_{K}(x)=\left\{\begin{array}{cc}
0 & 50 \leq x \leq 100 \\
(50-x) / 50, & 0<x \leq 50
\end{array}\right. \\
\mu_{C}(x)\left\{\begin{array}{cc}
0 & 0 \leq x \leq 30 \\
(x-30) / 20, & 30<x \leq 50 \\
(60-x) / 10, & 50<x \leq 60 \\
0, & 60<x \leq 100
\end{array}\right.
\end{gathered}
$$




$$
\begin{gathered}
\mu_{B}(x)\left\{\begin{array}{cc}
0 & 0 \leq x \leq 50 \\
(x-50) / 20, & 50<x \leq 70 \\
(80-x) / 10, & 70<x \leq 80 \\
0, & 80<x \leq 100
\end{array}\right. \\
\mu_{S B}(x)=\left\{\begin{array}{cc}
0 & 0 \leq x \leq 70 \\
(x-70) / 30, & 70<x \leq 100
\end{array}\right.
\end{gathered}
$$

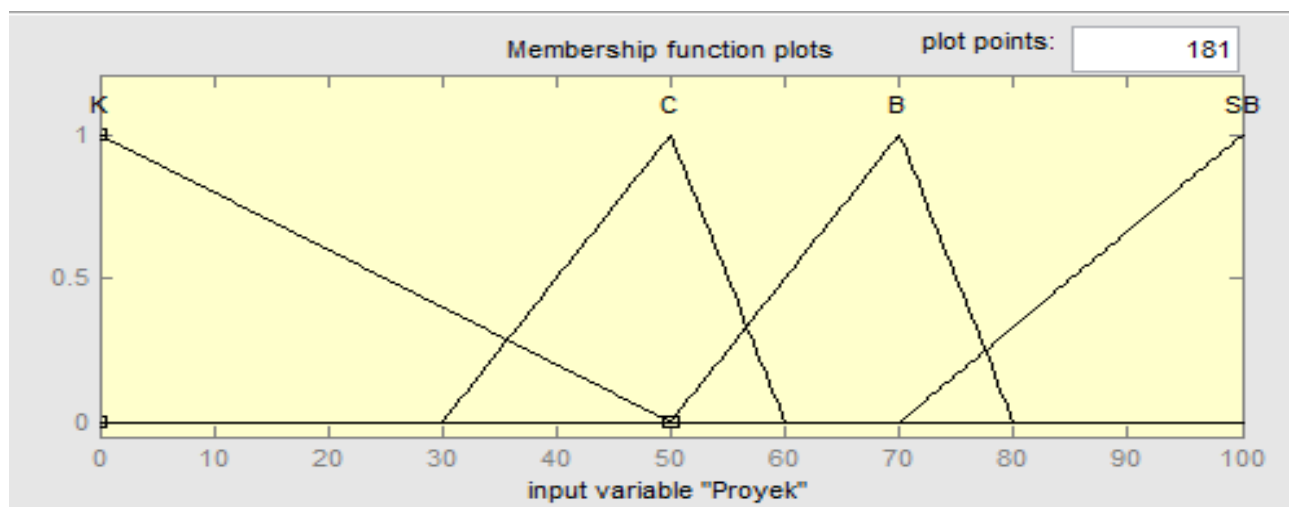

Gambar 3. Fuzzifikasi proyek

Pada Gambar 3 menunjukkan hubungan antara masing-masing tingkatan penilaian pada penilaian proyek siswa yang berperan sebagai input dengan fungsi keanggotaan fuzzy yang dibuat dengan menggunakan fungsi keanggotaan model segitiga.

Variabel input ketiga adalah penilaian presentasi proyek. Maka hubungan antara tingkatan nilai proyek dengan fungsi keanggotaannya dapat diulis:

$$
\begin{gathered}
\mu_{K}(x)=\left\{\begin{array}{cc}
0 & 40 \leq x \leq 100 \\
(40-x) / 40, & 0<x \leq 40
\end{array}\right. \\
\mu_{C}(x)\left\{\begin{array}{cc}
0 & 0 \leq x \leq 30 \\
(x-30) / 20, & 30<x \leq 50 \\
(65-x) / 5, & 50<x \leq 65 \\
0 & 65<x \leq 100
\end{array}\right. \\
\mu_{B}(x)\left\{\begin{array}{cc}
(x-60) / 10, & 60<x \leq 70 \\
(80-x) / 10, & 70<x \leq 80 \\
0 & 80<x \leq 100
\end{array}\right. \\
\mu_{S B}(x)=\left\{\begin{array}{cc}
0 & 0 \leq x \leq 75 \\
(x-75) / 25, & 75<x \leq 100
\end{array}\right.
\end{gathered}
$$




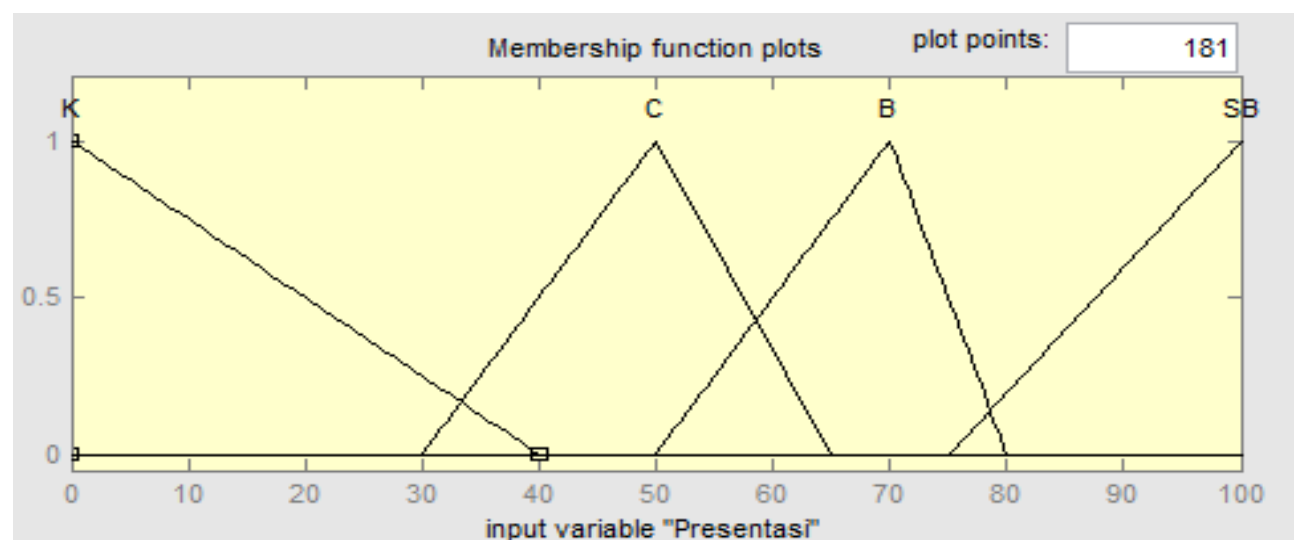

Gambar 4. Fuzzifikasi presentasi

Pada Gambar 4 menunjukkan hubungan antara masing-masing tingkatan penilaian pada penilaian presentasi proyek siswa yang berperan sebagai input dengan fungsi keanggotaan fuzzy yang dibuat dengan menggunakan fungsi keanggotaan model segitiga.

Variabel input keempat adalah penilaian tes tulis. Maka hubungan antara tingkatan nilai proyek dengan fungsi keanggotaannya dapat diulis:

$$
\begin{aligned}
& \mu_{K}(x)=\left\{\begin{array}{cc}
0, & 30 \leq x \leq 100 \\
(30-x) / 30, & 0<x \leq 30
\end{array}\right. \\
& \mu_{C}(x)\left\{\begin{array}{cc}
0, & 0 \leq x \leq 20 \\
(x-20) / 20, & 20<x \leq 40 \\
(60-x) / 20, & 40<x \leq 60 \\
0, & 60<x \leq 100
\end{array}\right. \\
& \mu_{B}(x)\left\{\begin{array}{cc}
0, & 0 \leq x \leq 40 \\
(x-40) / 20, & 40<x \leq 60 \\
(80-x) / 20, & 60<x \leq 80 \\
0, & 80<x \leq 100
\end{array}\right. \\
& \mu_{S B}(x)=\left\{\begin{array}{cl}
0 & 0 \leq x \leq 70 \\
(x-70) / 30, & 70<x \leq 100
\end{array}\right.
\end{aligned}
$$




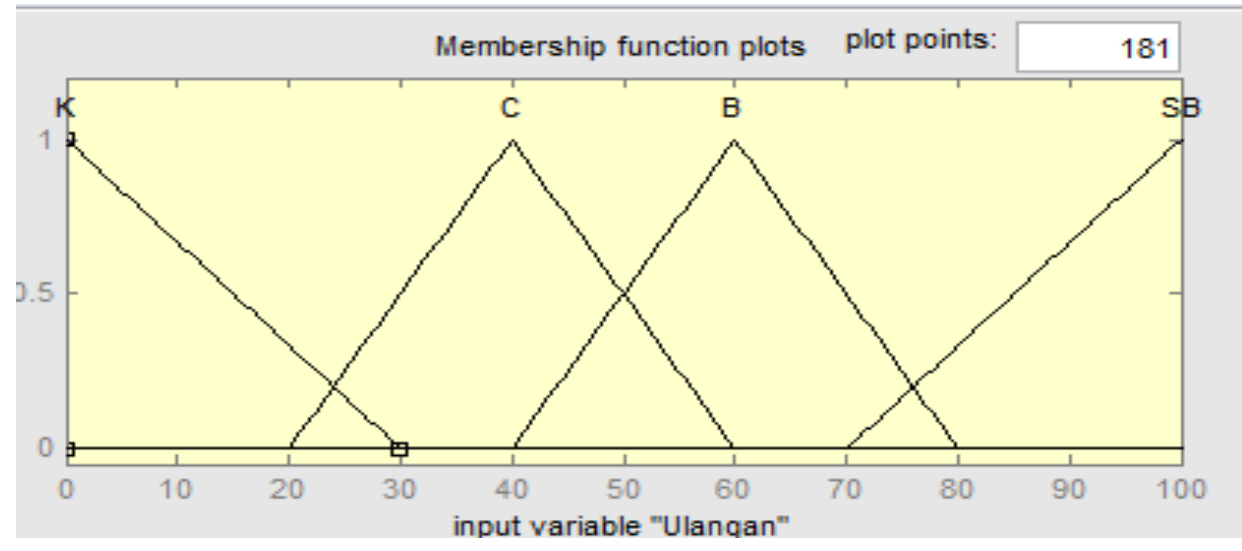

Gambar 5. Fuzzifikasi ulangan

Pada Gambar 5 menunjukkan hubungan antara masing-masing tingkatan penilaian pada tes tulis siswa yang berperan sebagai input dengan fungsi keanggotaan fuzzy yang dibuat dengan menggunakan fungsi keanggotaan model segitiga.

Variabel yang terakhir adalah variabel output. Hubungan antara tingkatan pada hasil akhir evaluasi dengan fungsi keanggotaannya dapat ditulis:

$$
\begin{aligned}
& \mu_{K}(x)=\left\{\begin{array}{cc}
0, & 50 \leq x \leq 100 \\
(50-x) / 50, & 0<x \leq 50
\end{array}\right. \\
& \mu_{C}(x)\left\{\begin{array}{cc}
0 & 0 \leq x \leq 30 \\
(x-40) / 15, & 30<x \leq 55 \\
(65-x) / 10, & 55<x \leq 65 \\
0, & 65<x \leq 100
\end{array}\right. \\
& \mu_{B}(x)\left\{\begin{array}{ccrl}
0 & & 0 \leq x \leq 60 \\
(x-60) / 15, & & 60<x \leq 75 \\
(85-x) / 10, & & 75<x \leq 85 \\
0, & 85<x \leq 100
\end{array}\right. \\
& \mu_{S B}(x)=\left\{\begin{array}{cl}
0 & 0 \leq x \leq 80 \\
(x-80) / 20, & 80<x \leq 100
\end{array}\right.
\end{aligned}
$$




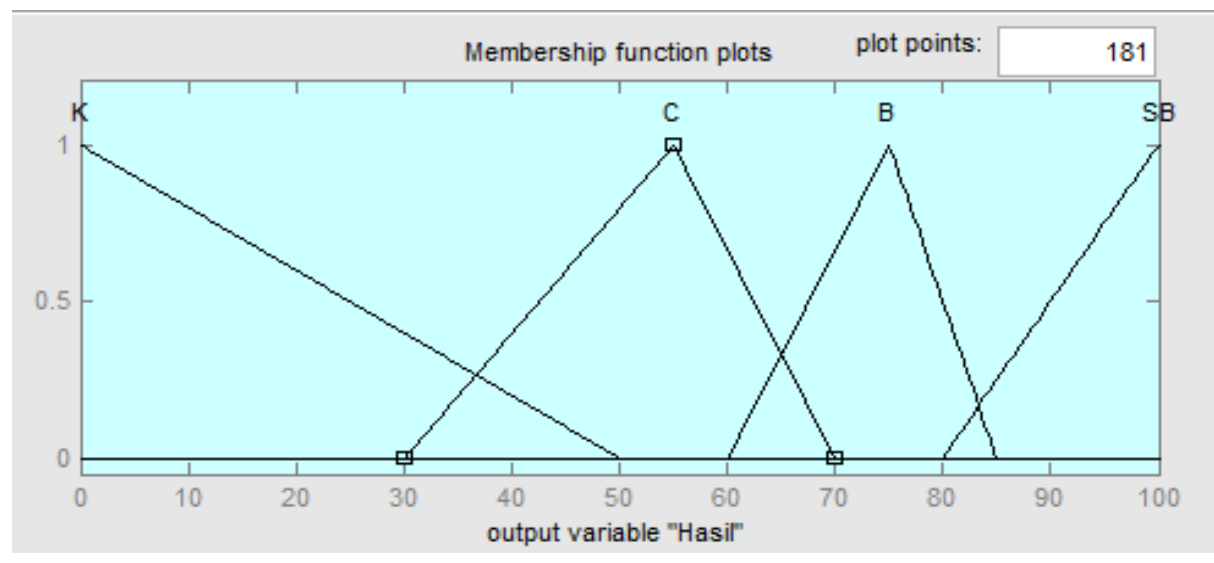

Gambar 6. Fuzzifikasi hasil

Pada Gambar 6 menunjukkan hubungan antara masing-masing tingkatan penilaian pada hasil akhir evaluasi yang berperan sebagai output dengan fungsi keanggotaan fuzzy yang dibuat dengan menggunakan fungsi keanggotaan model segitiga.

Semua variabel masukan dan keluaran telah didefinisikan dan bentuk fungsi keanggotaan untuk setiap nilai linguistik dari setiap variabel juga telah didefinisikan dan dilabeli. Langkah selanjutnya adalah mendefinisikan if-then rule.

Tahapan inferensi dibentuk dalam aturan "IF THEN" yang merupakan inti dari relasi fuzzy. Pada tahapan ini dibuat tabel hubungan antara input dan output sehingga dapat dibuat rule-base dari program fuzzy-nya. Karena input dari penilaian kinerja adalah portofolio, proyek, presentasi dan tes tulis maka rule-base dibuat seperti contoh berikut:

1. If Portofolio is Kurang and Proyek is Kurang and Presentasi Proyek is Kurang and Ulangan is Kurang Then Hasil is Kurang.

2. If Portofolio is Cukup and Proyek is Cukup and Presentasi Proyek is Cukup and Ulangan is Cukup Then Hasil is Cukup.

3. If Portofolio is Baik and Proyek is Baik and Presentasi Proyek is Baik and Ulangan is Baik Then Hasil is Baik. 
4. If Portofolio is Sangat Baik and Proyek is Sangat Baik and Presentasi Proyek is Sangat Baik and Ulangan is Sangat Baik Then Hasil is sangat Baik

5. Dan seterusnya.

Rules yang disepakati pada penelitian adalah sebanyak 256, dengan catatan setiap variabel input dan output ada pada setiap aturan yang dibangun seperti yang ditunjukan pada Gambar 7.

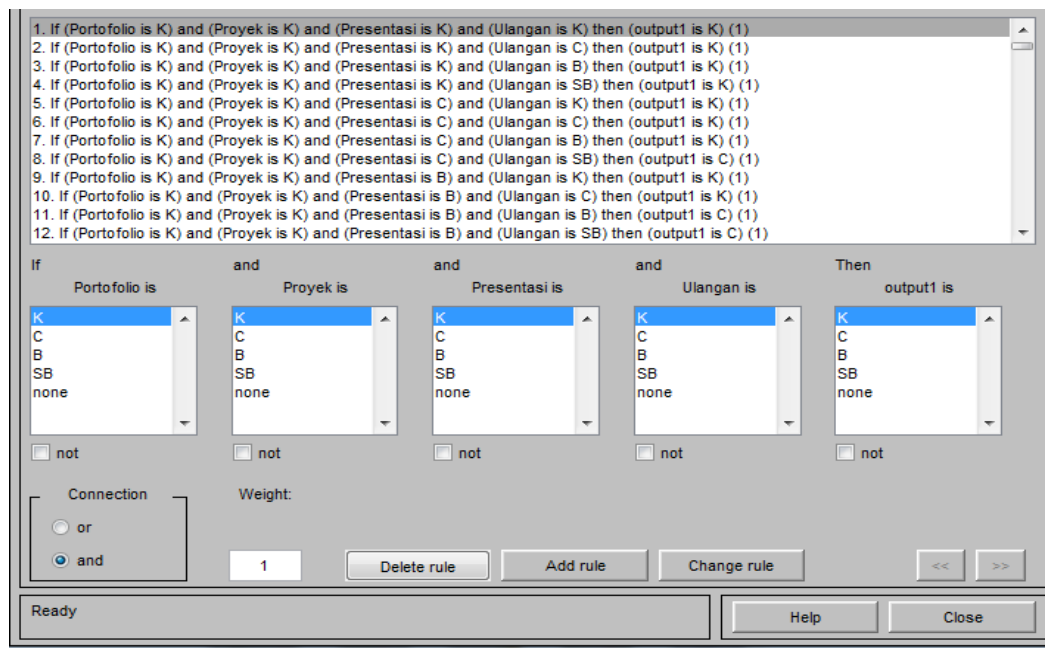

Gambar 7. Inferensi

Pada gambar 8. Menunjukan surface viewer yang memperlihatkan kehalusan dari gradasi warna pada perubahan tingkatan fuzzy dari aturan yang telah dibuat. Perubahan gradasi warna yang semakin halus menunjukan bahwa semakin bagus aturan yang telah dibangun.

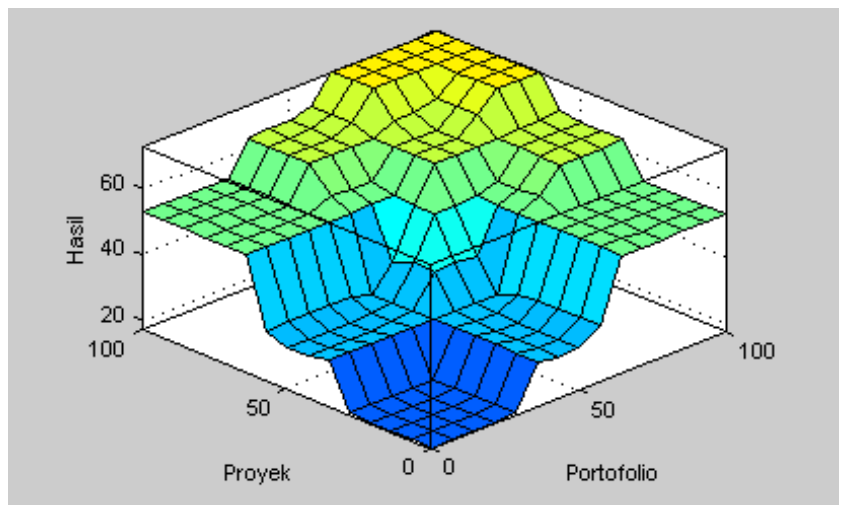

Gambar 8. Surface vierwer 
Tahap selanjutnya adalah defuzzifikasi. Proses defuzifikasi diperlukan untuk mendapatkan keluaran yang sesuai dengan masukan dan aturan-aturan yang telah dibuat bertujuan untuk merubah output fuzzy menjadi output non-fuzzy yang sesuai dengan pernyataan input dan output yang ditentukan. Dari hasil proses defuzzifikasi yang dilakukan kita sudah dapat menentukan keputusan nilai akhir siswa dengan cara memasukkan masing-masing hasil pengukuraan portofolio, proyek, presentasi dan tes tulis siswa. Berikut gambaran hasil defuzzifikasi pada penelitian terlihat pada Gambar 9.

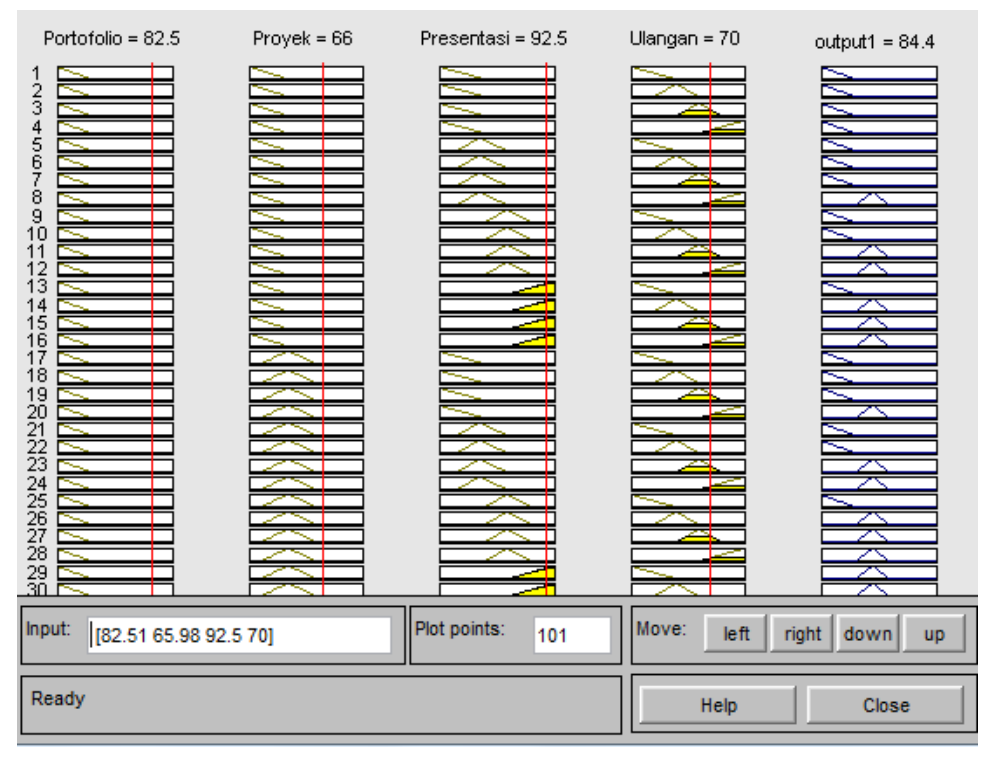

Gambar 9. Defuzzifikasi evaluasi PjBL

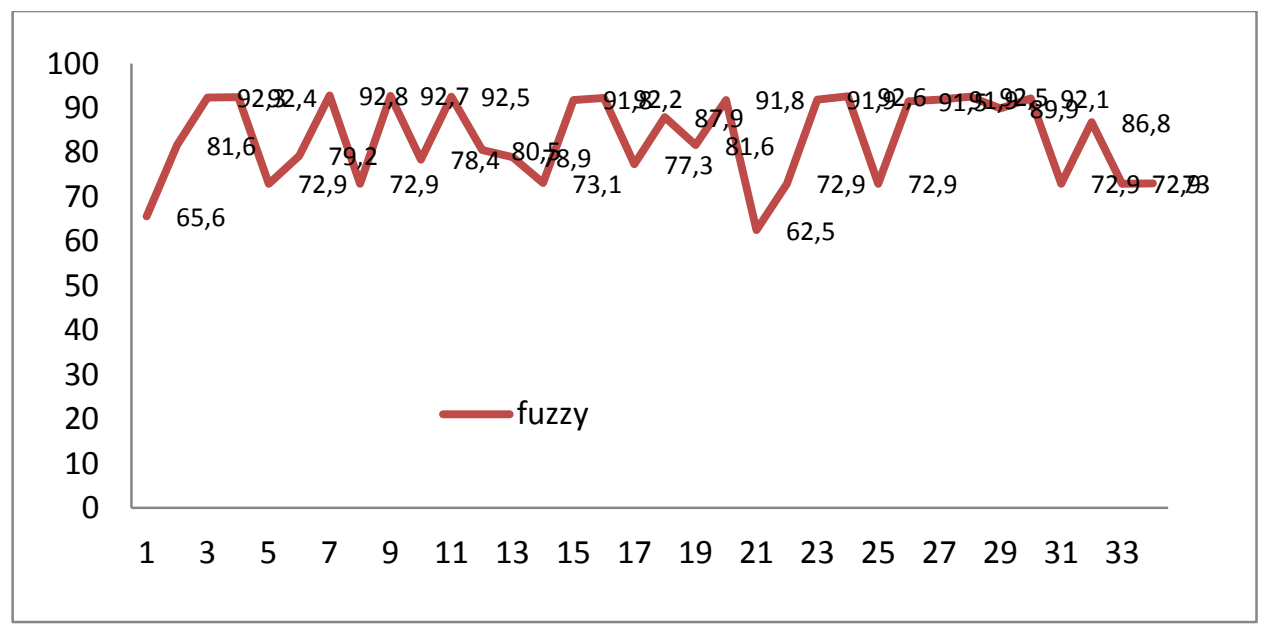

Gambar 10. Hasil evaluasi PjBL 
Gambar 10 menunjukan hasil evaluasi PjBL berbasis Logika fuzzy. Berdasarkan pembuatan evaluasi berbasis logika fuzzy, hasil tiga siswa menunjukan tiga perbedaan. Siswa A adalah siswa dengan perolehan hasil terbaik, siswa B dengan hasil rata-rata dan siswa C memperoleh hasil terendah. Derajat keangotaan himpunan fuzzy untuk penilaian portofolio siswa A menunjukan pada tingkatan "Sangat Baik", penilaian proyek menunjukan pada tingkatan "Sangat Baik", penilaian presentasi proyek menunjukan pada tingkatan "Sangat Baik" dan penilaian tes tulis menunjukan "Sangat Baik". Sedangkan untuk siswa B, derajat keanggotaan himpunan fuzzy untuk penilaian portofolio menunjukan pada tingkatan "Sangat Baik", penilaian proyek menunjukan pada tingkatan "Baik" dan "Sangat Baik", penilaian presentasi proyek pada tingkatan "Baik" dan penilaian tes tulis pada tingkatan "Baik". Dan untuk siswa C, derajat keanggotaan himpunan fuzzy untuk penilaian portofolio menunjukan pada tingkatan "Sangat Baik" dan "Baik", penilaian proyek pada tingkatan "B", penilaian presentasi proyek pada tingkatan "Kurang" dan penilaian tes tulis pada tingkatan pada tingkatan "Baik". Hasil yang diperoleh untuk ketiga siswa berdasarkan aturan (rule) yang ditetapkan, siswa A mendapat hasil akhir "Sangat Baik", siswa B mendapat hasil akhir "Baik" dan siswa C mendapat hasil akhir "Cukup".

Sebuah kasus terjadi pada siswa B untuk penilaian proyek, nilai yang diperoleh berada pada dua himpunan fuzzy pada tingkatan "Baik" dan "Sangat Baik", akan tetapi pada faktanya penilaian proyek siswa B mempunyai derajat keanggotaan yang lebih dekat pada tingkatan "Baik" daripada tingkatan "Sangat Baik”. Begitupun dengan siswa C yang memperoleh nilai portofolio yang berada pada dua himpunan fuzzy pada tingkatan "Sangat Baik" dan "Baik", dan pada faktanya penilaian portofolio siswa $\mathrm{C}$ mempunyai derajat keanggotaan yang lebih dekat pada tingkatan "Baik" daripada pada tingkatan "Sangat Baik". Hal lain yang menarik adalah sekalipun pada siswa $\mathrm{C}$ mendapatkan hasil yang gagal pada presentasi proyek, hasil portofolio dan penilaian yang lainnya telah masuk akal dalam menunjukan hasil belajar.

Setelah refleksi dari semua penilaian, hasil evaluasi diharapkan mendapatkan trend yang baik. Siswa telah berusaha menarik dan meningkatkan motivasi mereka dalam kegiatan portofolio, proyek, presentasi maupun tes tulis. 
Dalam pengamatan praktis menunjukan bahwa meskipun pencapaian tingkat keberhasilan hasil belajar bisa lebih tinggi atau rendah, hal itu mungkin tidak tercermin dalam nilai secara keseluruhan. Model evaluasi pembelajaran PjBL berbasis logika fuzzy bisa menjadi petunjuk untuk mengembangkan model evaluasi yang saat ini diadopsi di Sekolah. Dengan demikian, langkah-langkah yang disajikan meliputi kegiatan portofolio, proyek, presentasi, tes tulis dan evaluasi berbasis logika fuzzy telah sangat kuat berdasarkan bukti hasil observasi.

\section{KESIMPULAN}

Hasil rubrik-rubrik yang dikembangkan dan diterapkan pada $\mathrm{PjBL}$ adalah penilaian portofolio yang terdiri dari portofolio proses praktikum, portofolio tugas mandiri dan portofolio laporan praktikum sebagai penilaian praktikum. sedangkan rubrik penilaian proyek digunakan untuk menilai proses perencanaan, pembuatan serta hasil akhir dari produk dan rubrik presentasi dapat dijadikan ajang refleksi tugas proyek yang dikerjakan siswa. Rubrik-rubrik dapat memandu dan mempermudah guru dalam kegiatan penilaian dan untuk meningkatkan kualitas kerja siswa. Dengan rubrik penilaian dapat menjelaskan harapan dan mendorong siswa agar bertanggung jawab terhadap pekerjaan yang mereka buat.

Hal terpenting lainnya adalah dalam proses evaluasi diperlukan pendukung keputusan dari serangkaian kegiatan yang dilakukan pada PjBL. Logika fuzzy merupakan suatu alternatif alat pengambil keputusan yang dapat diaplikasikan untuk mengevaluasi hasil pembelajaran dan meningkatkan objektivitas hasil evaluasi karena seluruh hasil evaluasi diproses secara komputasi. Sebagai kesimpulan, penggunaan logika fuzzy tidak hanya untuk aplikasi dibidang teknologi dan rekayasa, tetapi juga dapat digunakan untuk evaluasi pembelajaran PjBL.

\section{DAFTAR PUSTAKA}

Arifin, Z. (2010). "Model-model Evaluasi Program". Makalah pada Jurusan Kurikulum dan Teknologi Pendidikan FIP UPI, Bandung.

Bai, S.M., Chen, S.M. (2008). "Evaluating students's learning achievement using fuzzymembership functions and fuzzy rules". Published by Elsevier, Expert Systems with Applications 34 (2008) 399-410. 
Gokmen, G., Akinci, T.C., Tektas, M., Onat, N. (2010). "Evaluation of Student Performance in Laboratory Application Using Fuzzy Logic". Published by Elsevier, Procedia Social and Behavioral Sciences 2 (2010) 902-909.

Ignoey, S., Bakal, J.W. (2012). "Use of Fuzzy Logic in Evaluating Students's Learning Achhivement". International Journal on Advanced Computer Engineering and Communication Technology (IJACECT). ISSN (Print): 2278-5140, Volume-1, Issue - 2, 2012.

Kusumadewi, S. dan Purnomo, H. (2010). Aplikasi Logika Fuzzy Untuk Pendukung Keputusan. Yogyakarta: Graha Ilmu.

Nykänen, O. (2006). "Inducing Fuzzy Models for Student Classification". Educational Technology \& Society, 9 (2), 223-234.

Pardjono, dan Windiyati, H. (2012). "Implementasi Pembelajaran Berbasis Kompetensi di SMK”. Cakrawala Pendidikan, Juni 2012, Th, XXXI, No. 2.

Rohman, A. (2007). "Masalah Pembelajaran dan Pemecahannya". Makalah pada seminar Nasional Inovasi Pembelajaran, Jakarta.

Rustaman, N.Y. (2006). "Penilaian Otentik (Authentic Assessment) dan Penerapannya Dalam Pembelajaran Sains”. FPMIPA \& Sekolah Pascasarjana UPI, Bandung.

Sudijono, A. (2012). Pengantar Evaluasi Pendidikan. Jakarta: rajawali Pers.

Wena, M. (2009). Stragegi Pembelajaran Inovatif Kontemporer: Suatu tinjauan Konseptual Operasional. Jakarta: Bumi Aksara.

Yussof, D.H.B.H. (2006). Project Based Learning Handbook "Educating the Millenial Learner". Educational Technology Division, Ministry of Education.

Zou, D., Kwok, R.C.W., Zhang, K., Ma, J. (2001). “A New Method for Student Project Assessment Using Fuzzy Set". Authorized licensed use limited to: TOKYO INSTITUTE OF TECHNOLOGY. Downloaded on November 18, 2008 at 21:38 from IEEE Xplore. 